\title{
DES-, MATA- JA MAKS-KONVERBITARINDI INFOROLL
}

\author{
Carl Eric Simmul \\ Tartu Ülikool, EE \\ carl.eric.simmul@ut.ee
}

\begin{abstract}
Kokkuvõte. Artikkel käsitleb eesti keele des-, mata- või maks-konverbitarindit sisaldavat komplekslauset. Aluseks on kvalitatiivne uurimus, mille käigus on analüüsitud 1803 konverbitarindit sisaldava lause semantilisi, morfosüntaktilisi ja infostruktuurilisi tunnuseid. Antakse ülevaate sellest, missuguseid inforolle täidab konverbitarind põhilause suhtes ja missuguste teguritega seostub konverbitarindi inforolli varieerumine. Uurimusest selgub konverbitarindi neli põhilist inforolli: 1) raamistav teema, 2) reema taustaosa, 3) fookus ja 4) omaette infoüksus. Konverbitarindi inforoll seostub tihedalt sõnajärjega, nii konverbi kui ka tarindi asukohaga. Konverbialguline tarind toimib tavaliselt omaette infoüksusena, konverbilõpuline ja ühesõnaline tarind aga moodustavad põhilausega ühise infoüksuse. Tarindi inforoll oleneb seejuures tarindi asukohast: konverbilõpuline või ühesõnaline eestarind toimib tavaliselt raamistava teemana, sisetarind reema taustaosana ja järeltarind fookusena. Teistest teguritest seostuvad konverbitarindi inforolliga nt kirjavahemärgistus, põhilause kommunikatiivne tüüp, fookustavad üldlaiendid, konverbi laiendite pikkus ja struktuur ning semantiline funktsioon.
\end{abstract}

Märksõnad: des-tarind, mata-tarind, maks-tarind, konverb, sõnajärg, infostruktuur, süntaks, semantika, eesti keel

DOI: https://doi.org/10.12697/jeful.2021.12.1.08

\section{Infostruktuur ja konverbitarind}

Käsitlen artiklis des-, mata- ja maks-konverbitarindi infostruktuuri kirjakeeles, jätkates sellega eesti keele konverbitarindi uurimist ja avardades infostruktuurikäsitluste haaret. Vaatlen kirjalikke konverbitarindit sisaldavaid komplekslauseid, mille infostruktuuri pole seni põhjalikult käsitletud. Juhatan artikli sisse infostruktuuri põhimõistete tutvustusega, misjärel räägin komplekslause infostruktuurist ning annan ülevaate konverbitarindi süntaktilisest kategooriast ja eesti konverbitarindi varasema uurimise tulemustest. 


\subsection{Infostruktuuri põhimõisted}

Terviklikul keelekonstruktsioonil, nt lausel, on semantiline ja pragmaatiline tasand. Semantiliselt tähistab konstruktsioon sündmust: selle laadi, aega, kohta ja osalisi. Pragmaatiliselt väljendab konstruktsioon keelekasutaja suhtluseesmärki ja esitatava info seost kontekstiga - ehk infostruktuuri (Erelt 2017a: 53).

Infostruktuuri analüüsimise tasandil (edaspidi infotasand) koosneb keelekasutus infoüksustest (Halliday 1967, Chafe 1976, Moore 2016). Infoüksusel on leksikaalseid ja grammatilisi tunnuseid, nt prosoodia ja sõnajärg, mis olenevad sellest, missuguseks peab keelekasutaja vastuvõtja teadvusseisundit, nt tähelepanu ja teadmisi. Selliste tunnuste põhjal analüüsitakse keeleüksuse infostruktuuri (Nikolajeva 2001: 1-3, Lindström 2017: 537, Matić \& Nikolajeva 2018: 2).

Infotasandil on analüüsitud peamiselt kirjalikku elementaarlauset, lähtudes kolmest vastandusest: 1) uue ja vana info, 2) teema (topiku) ja reema (kommenti), ning 3) tausta ja fookuse vastandusest (Zimmermann \& Féry 2010: 1-2, Amon 2015: 21, Lindström 2017: 537, Adamou, Haude \& Vanhove 2018: 1). Kõige ilmekamalt vastanduvad infotasandil teema ja fookus (Lambrecht 1994). Tüüpiline teema väljendab tuntud infot ja paikneb infoüksuse alguses ning tüüpiline fookus väljendab uut infot ja paikneb infoüksuse lõpus. Infoüksussisene vastandus võib ka puududa: kui teema on implitsiitne ja infoüksuse ükski osa pole esile tõstetud, moodustab infoüksus ühtse terviku - nn lausefookuse (Lambrecht 2000: 612, Lindström 2017: 545).

Ehkki infostruktuuri põhimõistete üldsisu suhtes ollakse paljuski ühel meelel, varieeruvad täpsemad määratlused käsitluste kaupa (Zimmermann \& Féry 2010: 2). Kategooriad, mille põhjal infostruktuuri käsitletakse, pärinevad erinevatest teoreetilistest raamistikest ning infostruktuurimõistete ja -terminite vahel valitsevad mitu mitmele seosed (Gundel \& Fretheim 2004: 175, Amon 2015: 21-30, Adamou, Haude \& Vanhove 2018).

\subsection{Komplekslause infostruktuur}

Infostruktuurikäsitlused on tegelnud eelkõige kirjaliku elementaarlausega. Suulisi (Lindström 2005, Amon 2015: 22) ja kompleksseid konstruktsioone on hakatud käsitlema hiljem ja on käsitletud vähem. 
Komplekslause infostruktuur, millele on viimastel aastatel hakatud rohkem tähelepanu pöörama (vt van Gijn et al 2014), võib hõlmata põhilausele lisaks üht või mitut sündmust väljendavat moodustajat ehk klausi (Matić, van Gijn \& van Valin 2014: 1, Erelt 2017b: 647). Klausi puhul on vaadeldav nii välimine kui ka sisemine infostruktuur: välimise infostruktuuri all peetakse silmas klausi inforolli komplekslauses ja sisemise infostruktuuri all klausi moodustajate inforolli klausi sees (Matić, van Gijn \& van Valin 2014: 9-10).

Infotasandil on käsitletud kõrvallauset sisaldavaid komplekslauseid (van Putten 2014, Reesink 2014), misjuures on vaadeldud nii määruslauset (van der Wal 2014), komplementlauset (Ibarluzea 2014) kui ka relatiivlauset (Komen 2014, Storto 2014) sisaldavaid lauseid. Sellele lisaks on puudutatud põgusalt infinitiivtarindit sisaldavaid komplekslauseid (Matić, van Gijn \& van Valin 2014: 6-7, 18-19). Siinne artikkel laiendab infostruktuurikäsitluste ulatust, võttes vaatluse alla konverbitarindit sisaldavad laused.

\subsection{Eesti konverbitarind}

Konverbitarind on klaus, mille tuum on infiniitne verbivorm ja mis toimib sündmust väljendava konstruktsiooni vaba laiendina (Haspelmath 1995: 3, Nedjalkov 1998: 340, Ylikoski 2003: 222, Khalilova 2009: 216). Järgnevas nimetan konstruktsiooni, mida konverbitarind laiendab, olenemata struktuurist põhilauseks ning konverbitarindi ja põhilause tervikut komplekslauseks.

Eesti keele konverbitarindid on des-, mata- ja maks-tarind. Seni on nende konstruktsioonide puhul tähelepanu pälvinud tegevussubjekt (Uuspõld 1966, 1972, Sahkai 2011, Plado 2015b, Erelt 2017c: 809814), funktsioonid ja polüseemia (Uuspõld 1966, Valijärvi 2003, Plado 2015a, Erelt 2017c: 814-819, Simmul 2018) ning sõnajärg (Martõkainen 2015, Simmul 2020). Siin artiklis võtan vaatluse alla konverbitarindi välimise infostruktuuri ehk inforolli põhilause suhtes.

Konverbitarindid jagunevad eksplitsiitse ja implitsiitse tegevussubjektiga tarinditeks (Plado 2015b). Konverbitarindi implitsiitse tegevussubjektina tõlgendub kõneolukorra kõige esilduvam osaline (Haspelmath 1995: 36, Plado 2015b: 338). Implitsiitse tegevussubjektiga tarindi mall on eesti keeles produktiivsem ja suurema tüübisagedusega 
kui eksplitsiitse tegevussubjektiga tarindi mall, kus tegevussubjekti väljendab omastavaline valdajamäärus, nn genitiivagent (Sahkai 2011).

Konverbitarindi polüseemia on tähelepanu pälvinud nii eesti keeles kui ka teistes keeltes (Kortmann 1991, König 1995, Nedjalkov 1998, Killie \& Swan 2009). Siin lähtun konverbitarindi funktsiooni kahetasandilisest käsitusviisist (Simmul 2018), mille alusel täidab tarind põhilause suhtes alati baasfunktsiooni, millel on kaks avaldumiskuju: AEG ja KAASNEMINE. AJA baasfunktsiooniga tarind (näide 1) väljendab põhilause sündmuse ajalist konteksti, KAASNEMISE baasfunktsiooniga tarind (2) aga mitte, asetudes enamasti ise põhilause konteksti. Näites 1 väljendab AJA baasfunktsiooniga tarind villasse sisenedes põhilause sündmuse toimumisaega. Näites 2 tarindil jälgides .. sellist funktsiooni aga pole ja tarindi sündmus asetub ise põhilause sündmuse konteksti.

(1) Juba villasse sisenedes oli ta imestuse ja õudusega märganud seintel mitmesuguseid maale ja litograafiaid vampiiridest (ILU). ${ }^{1}$

(2) Ta nihutas end mugavamasse asendisse, jälgides, et tooli kiikumine ei ületaks pokaali püsivust (ILU).

Baasfunktsioonile lisaks võib tarind täita põhilause suhtes lisafunktsiooni, milleks võib olla OTSTARVE (näide 3), viIS (4), PõHJUs (5), VAHEND, TULEMUS, TÄPSUSTUS, TINGIMUS, MÖÖNDUS Või VASTANDUS. Peale selle esineb mitu lisafunktsioonide kombinatsiooni (Simmul 2018, Simmul 2020: tabel 2). Lisafunktsioon liitub baasfunktsioonile, st baasfunktsioon jääb lisafunktsiooni taustal alles. Nii kannavad tarindid näidetes 3-5 KAASNEMISE ja tarind näites 6 AJA baasfunktsiooni. Näites 3 väljendab tarind andmaks .. põhilause sündmuse eesmärki. Näites 4 väljendab kaks tarindit põhilauses väljendatud kokkuostmise viIsI. Näites 5 väljendab tarind põhilause sündmuse PõHJUST. Näites 6 on konverbitarindi sündmus mõistetav hüpoteetilise vaHENDINA, mille abil võib jõuda põhilauses esitatud olukorrani ja mis ühtlasi toimib selle olukorra ajalise raamistikuna.

1 Näitelausetes on vaatlusalune konverbitarind poolpaksus kirjas. Näitelause järel olev lühend viitab lause allikkorpusele. Lühend ILU näitab, et lause pärineb eesti kirjakeele korpuse ilukirjandustekstide katkendite korpusest, lühend AJA, et lause pärineb eesti kirjakeele korpuse ajakirjandustekstide korpusest, ja lühend TK, et lause pärineb tasakaalus korpusest. 
(3) Seadusandlikult saaks näiteks luua ajateenistuse läbimise positiivse ja negatiivse motiveerimise süsteemi, andmaks sõdurile mõtet teenida (TK).

(4) Praegu suunavad NSV Liidu nn kuuenda variandi kokkuostuhinnad selle võidukale lõpule endises suunas, jättes kõik endist viisi, s.t kokku ostetakse ilma kvaliteedi järgi eristamata, arvestades vaid suurenevaid tootmiskulusid (AJA).

(5) Teadmata täpselt isegi, mida karta, kiirustas ta kohemaid kloostrisse tagasi (ILU).

(6) Mu isa lihtsad juhised näivad turvalise pesapaigana, mida ustavalt järgides on ehk lootust suure maailma teisitiolemise suhtes olla aeg-ajaltki kurt ja pime (ILU).

des-tarindil on kaks baasfunktsiooni, mata-tarindil esineb ainult KAASNEMISE baasfunktsioon. Et maks-tarind kannab alati OTSTARBE funktsiooni, pole baas- ja lisafunktsiooni eristus maks-tarindi puhul vajalik. Siin artiklis käsitlen maks-tarindi funktsiooni süsteemsuse huvides siiski KAASNEMISE baasfunktsiooni ja OTSTARBE lisafunktsiooni kombinatsioonina.

Konverbitarindi asukoht varieerub. Tarind võib paikneda põhilause ees (eestarind) (7), sees (sisetarind) (8) ja järel (järeltarind) (4). Tarindi asukoha varieerumine seostub baas- ja lisafunktsiooniga ning vähemal määral konverbi asukoha ja tarindi pikkusega. Eesasend seostub tihedalt AJA baasfunktsiooniga $(1,6)$; seesasend tarindi konverbilõpulisuse ja ühesõnalisusega ning järelasend KAASNEMISE baasfunktsiooni, OTSTARBE, TULEMUSE, TÄPSUSTUSE ja VASTANDUSE lisafunktsiooni, tarindi konverbialgulisuse ja suurema pikkusega $(4,9)$ (Simmul 2020: 234).

(7) Sü̈̈̈es meenus mulle hea tuttav, Kihnu mees Köster, „Reinu“ kapten (ILU).

(8) Mina lahmasin Pustile pikemalt aega viitmata vasaku haagiga vastu hambaid (ILU).

Varieerub ka konverbi asukoht tarindis. Tavaliselt asub konverb esimesel (näide 5) või viimasel (8) kohal, vähem esineb ühesõnalisi 
tarindeid (7) ja väga harvad on tarindi sees paikneva konverbiga juhud (20-21). Tarindid, mis kannavad MöÖNDUSE, OTSTARBE (3), TULEMUSE, PÕHJUSE (5) või TÄPSUSTUSE lisafunktsiooni, on enamasti konverbialgulised. Teiste lisafunktsioonide puhul seostub konverbi asukoht eelkõige tarindi pikkusega: mida pikem tarind, seda rohkem konverbialgulisi tarindeid; mida lühem tarind, seda rohkem konverbilõpulisi tarindeid (Simmul 2020: 236).

\subsection{Uurimisküsimused ja terminid}

Kui seni on komplekslause infostruktuuri puhul põhitähelepanu pälvinud kõrvallause, siis siin artiklis tulevad vaatlusele tegurid, mis seostuvad konverbitarindi inforolliga. Määruslause - millega konverbitarind täidab samasugust süntaktilist funktsiooni - võib toimida nii komplekslause teemana kui ka reema osana, mh fookusena (vt Thompson, Longacre \& Hwang 2007, van Gijn et al 2014: 12, van der Wal 2014: 62, Kinberg 2001). Allpool vaatlen, kas konverbitarind täidab samasuguseid inforolle.

Täpsemalt selgitan välja, kas, ja kui, siis millistel tingimustel võib konverbitarind toimida omaette infoüksusena või komplekslause (raamistava) teemana, reema taustaosana ja fookusena. Järgmiseks annan neist inforollidest ülevaate.

\subsubsection{Infoüksus}

Infoüksus on infotasandi tervik: konstruktsioon, millel on omaette infostruktuur. Lähtun infoüksuse mõiste kirjeldamisel eelkõige Halliday $(1967,1985)$ käsitusviisist, millele lisaks arvestan Chafe'i $(1979,1982)$ ideeüksuse mõistega.

Nagu keelekasutus jaguneb süntaktilisel tasandil süntaktilisteks lauseteks ja fraasideks ning prosoodilisel tasandil intonatsioonifraasideks, jaguneb see infotasandil infoüksusteks (Halliday 1967). Infoüksuse avaldumisvormina on kõnes käsitletud intonatsioonifraasi (Halliday 1967, 1985): igale infoüksusele vastab terviklik intonatsioonikontuur (Asu et al. 2016: 161). Kirjas on infoüksuse avaldumisvormina käsitletud punktuatsiooniüksust ja indikaatorina kirjavahemärke (inglise keele kohta vt Chafe 1988, Moore 2016). 
Infotasand ja süntaktiline tasand ei seostu üheti (Halliday 1967: 201). Vaikimisi hõlmab infoüksus Halliday järgi üht põhilauset ja sellele alistatud klause, kui neid leidub (Halliday 1967: 201). Suulises kõnes vastab intonatsioonifraas ja ühtlasi infoüksus aga lihtlausele või fraasile (Asu et al. 2016: 161). Selle põhjal otsustades võib alistatud klaus toimida ka omaette infoüksusena.

Halliday järgi (1985: 275) sisaldab infoüksus uut infot ja võib sisaldada tuntud infot. Laiendan käsitusviisi: infoüksus sisaldab fookust ning võib sisaldada teemat ja reema taustaosa. Vähim infoüksus toimib (lause)fookusena (Lambrecht 2000: 612).

Tüüpiline infoüksus koondab keelekasutajate tähelepanu ühele infokillule. Igal infoüksusel on omaette fookus ja infostruktuur, mis eristub eelneva ja järgneva infoüksuse struktuurist, nii et iga infoüksus toimib suhtelise tähendusliku tervikuna.

\subsubsection{Fookus, teema ja reema}

Matići ja Wedgwoodi (2013) järgi on fookus probleemne kategooria (vt ka Matić 2009). Esiteks määratletakse seda sageli ähmaselt või jäetakse määratlemata. Tegelikult ei olegi aga Matići ja Wedgwoodi järgi võimalik määratleda kategooriat, mis hõlmaks kõiki traditsiooniliselt fookusega seostatud nähtusi, sest fookuse mõistel pole üht kindlat tähenduskomponenti ega ühtsel fookusekategoorial empiirilist alust (Matić \& Wedgwood 2013: 132, 143). Fookusega on seostatud nii erinevaid keelendeid, et käsitledes neid ühe nähtuse avaldumisvormina, tuleks paratamatult mööda vaadata olulisest keelelisest mitmekesisusest (Matić \& Wedgwood 2013: 134-135, 137-143). Siiski on fookus kasulik katustermin, mis koondab selliseid konkreetsemaid pragmaatilisi tunnuseid nagu emfaas (tunderõhk), kontrast, infoüksuse propositsioonilisus ja info uudsus (Matić \& Wedgwood 2013: 141, 158-159, Lambrecht 1994: 213).

Mitme pragmaatilise tunnusega on seostatud ka teemat (Ebert 2009: 19 jj, Amon 2015: 25). Ühe põhilise määratluse alusel on teema infoüksuse osa, mille kohta ülejäänud infoüksus ehk reema infot annab (Reinhart 1981, Lambrecht 1994: 118, Ebert 2009: 20). Sisult lähedase määratluse järgi on teema teate lähtepunkt - ja reema sihtpunkt (Lindström 2017: 540). Sageli seostatakse teemat info tuntusega, 
st asjaoluga, et teemana toimiva moodustaja referent on vastuvõtjale keelekasutaja meelest tuttav (Haiman 1978: 583 jj, Ebert 2009: 21-22). Samuti on peetud teemale omaseks seda, et teema määratleb raamistiku, mille piires kehtib infoüksuse abil esitatav väide (Chafe 1976: 50, Thompson \& Li 1976: 463-464). Teemat on seostatud ka positsiooniga infoüksuse alguses ja keelekasutajate tähelepanu keskmes (Thompson \& Li 1976: 464-466, Nikolajeva 2001: 4). Ehkki nimetatud tunnused esinevad sageli koos, võib mõni tunnus avalduda konkreetse infoüksuse teema puhul selgemalt kui teine (Halliday 1967, Reinhart 1981, Krifka 2007). Seda silmas pidades sobib ka teemat käsitleda katusterminina, mis koondab konkreetsemaid tunnuseid, nt tuntust, lähtepunktilisust, lausealgulisust ning asjaolusid, et ülejäänud infoüksus käib selle kohta ja see piiritleb väite raamistikku.

Eesti keeleteaduses on eristatud primaarset ja sekundaarset teemat (Tael 1988, Lindström 2017). See, missugust konstruktsiooni käsitletakse infoüksuse primaarse teemana, oleneb infoüksuse struktuurist. Enamasti toimib primaarse teemana tegevussubjekt, mis asub tüüpilise infoüksuse alguses (Erelt 2017a: 84-85). Sekundaarse teemana käsitletakse elementi, mis pole primaarne teema, aga paikneb mingite kontekstiliste tegurite mõjul infoüksuse alguses ja pakub infoüksusele alternatiivset, sageli kontekstisidusat lähtekohta (Lindström 2017: 538-539, 552).

Konverbitarindi inforolli kirjeldamisel kasutan raamistava teema ${ }^{2}$ mõistet, mida käsitlen sekundaarse teema alltüübina. Raamistav teema väljendab infoüksuse põhiväite vahetut konteksti (Chafe 1976: 51, Jacobs 2001: 656, Krifka 2007: 45-46, Krifka \& Féry 2008: 129). Näites 9 kontekstualiseerib raamistav teema Seda melu kuuldes infoüksuse tuumväidet naised hakkasid kõrvaltoas karjuma. Raamistav teema hõlmab ülejäänud infoüksuse tervikuna, misjuures üksuse infostruktuuri võib kujutada nii: [raamistav teema [primaarne teema + reema]] $\mathrm{IÜ} \mathrm{(vt}$ ka Jacobs 2001: 657).

(9) $\left[[\text { Seda melu kuuldes }]_{\mathrm{RT}} \text { hakkasid }[\text { naised }]_{\mathrm{PT}} \text { kõrvaltoas }[\text { karjuma }]_{\mathrm{F}}\right]_{\mathrm{IU}}$ $(\mathrm{AJA})^{3}$.

2 Tänan anonüümset retsensenti, kes soovitas seda mõistet kasutada.

3 Näitelausetes on infoüksus, fookus, primaarne, raamistav ja kontrastiivne teema eraldatud nurksulgudega ning infotasandi moodustaja rolli tähistab kinnisulujärgne lühend (vastavalt IÜ, F, PT, RT ja KT). Täpsemalt vt näitelausete analüüsi ja märgenduse kohta jaotis 2 . 
Raamistavaid tarindeid, mis väljendavad millelegi vastandatud sündmust, käsitlen kontrastiivse teemana (kontrasti kohta vt lähemalt Neeleman et al 2009). Näites 10 toimib kontrastiivse teemana tarind sisuliselt arutades, mis on vastandatud eelneva infoüksuse raamistavale teemale Lähtudes ..

(10) $\left[[\text { Lähtudes formaalselt seaduse tekstist }]_{\mathrm{RT}}\right.$, tuleb [nendest piirmääradest kõrgem üür $]_{\mathrm{PT}}$ lugeda $\left.[\text { mittetöiseks tuluks }]_{\mathrm{F}}\right]_{\mathrm{IÜ}}$. [[Sisuliselt arutades $]_{\mathrm{KT}}$ kujuneb aga [pilt $\left.]_{\mathrm{PT}}[\text { mõnevõrra teiseks }]_{\mathrm{F}}\right]_{\mathrm{IU}}$. (AJA)

Reema on teate sihtkoht, mis annab infot primaarse teema kohta ja hõlmab kogu infoüksuse, v.a teema(d). Reema koosneb fookusest ja taustaosast või ainult fookusest. Kui ükski reema osa ei tõuse ülejäänu suhtes esile, langeb reema ühte fookusega. Kui mõni reema osa on ülejäänu suhtes esile tõstetud, toimib see fookusena ja ülejäänud reema selle taustana. Konverbitarind võib toimida nii infoüksuse fookusena (11) kui ka reema taustaosana (12).

(11) [Jäta too Roosenhill ilma [tööta $\left.]_{\mathrm{F}}\right]_{\mathrm{IU}}-\mathrm{ja}\left[\mathrm{[ta}_{\mathrm{PT}}[\right.$ nõuab keskmist Angola tasu ka $\left.[\text { remondis logeldes }]_{\mathrm{F}}\right]_{\mathrm{IÜ}},\left[[\text { reservist }]_{\mathrm{F}} \text { rääkimata }\right]_{\mathrm{IU}}(\mathrm{ILU})$.

(12) $\left.\left[[\text { See katkendlikult röminal öeldu }]_{\mathrm{PT}} \text { ei lähendanud poega [isale }\right]_{\mathrm{F}}\right]_{\mathrm{IU}}$, $\left.\left[[k e s]_{\mathrm{PT}} \text { terekätt ulatamata last vaid [põrnitses }\right]_{\mathrm{F}}\right]_{\mathrm{IU}}$ (ILU).

\section{Materjal ja metoodika}

Artikkel põhineb kvalitatiivsel korpusuurimusel, mille andmestik pärineb eesti kirjakeele korpuse ja tasakaalus korpuse tekstidest ning koosneb des-, mata- ja maks-tarindit sisaldavatest lausetest. des- ja mata-tarindit sisaldavad laused pärinevad ajakirjandus- (AJA; 865000 sõnet) ja ilukirjandustekstide (ILU; 602000 sõnet) katkendite korpusest (https://www.cl.ut.ee/korpused/) ning maks-tarindit sisaldavad laused ajakirjandus-, ilukirjandus- ja teadusregistrit sisaldavast tasakaalus korpusest (TK; 15 miljonit sõnet; http://www.keeleveeb.ee/).

Esmalt kogusin kõik korpustes esinevad mata-konverbitarindid (kokku 1255) ja seejärel viiendikust samade korpuste tekstidest võrreldava hulga (1025) des-tarindeid. Sealt hulgast eraldasin leksikaliseerunud ja grammatiseerunud tarindid (vt Simmul 2017: 18-23), mille 
tulemusel jäi uurimismaterjali hulka 478 produktiivse malli mata- ja 825 produktiivse malli des-tarindit. Viimaks kogusin proportsionaalse hulga (500) maks-tarindeid. Selle tulemusel koosneb uurimismaterjal 1803 konverbitarindist koos kontekstiga.

Kirjeldan konverbitarindi inforolli kvalitatiivselt, tuginedes semantilistele, morfosüntaktilistele ja infostruktuurilistele tunnustele. Semantilisel tasandil vaatlen tarindi baas- (2 taset) ja lisafunktsiooni (10 taset), lähtudes varem tutvustatud käsitusviisist (Simmul 2018).

Morfosüntaktilisel tasandil käsitlen pisteliselt kümmet tunnust: konverbi asukoht tarindis, tarindi asukoht põhilause suhtes, tarindi pikkus sõnades (vt lähemalt Simmul 2020), tarindis sisalduvate laiendite hulk, tarindit eraldavad kirjavahemärgid, tarindis sisalduvad klausid (sündmuslikud konstruktsioonid, v.a nimisõnafraasid), tarindis sisalduvad konnektiivid-korrelaadid-sidesõnad, tarindit fookustavad laiendid, tarindit alistav kaassõna ilma.

Infotasandil vaatlen konverbitarindi inforolli, mille puhul eristan nelja taset: 1) omaette infoüksus, 2) raamistav teema (mille all-liik on kontrastiivne teema), 3) reema taustaosa, 4) fookus.

Nimetatud tunnustest ja nende kategooriatest ehk variantidest, mida olen materjali analüüsimisel eristanud, annab ülevaate tabel 1, kus on esitatud analüüsitavas materjalis esinenud juhtumite täisloend, mis aga ei ammenda mõnd nähtust, nt fookustavaid laiendeid.

Töö kvalitatiivses analüüsiosas pole kõiki juhtumeid kirjeldatud kõigi tunnuste abil, vaid on keskendutud konkreetse nähtuse olulistele tunnustele.

Näitelausetes olen läbipaistvuse huvides märgendanud kogu näite infostruktuuri. Iga näide koosneb ühest või mitmest infoüksusest. Igal infoüksusel on fookus ning võib olla primaarne teema, reema taustaosa ja sekundaarne, sh raamistav või kontrastiivne teema.

Primaarse teema kindlaksmääramisel lähtun infoüksuse struktuurilistest ja semantilistest omadustest, võttes arvesse infoüksuse kui lause struktuuri- ja kommunikatiivset tüüpi ning (umb- ja üld)isikulisust. Enamasti käsitlen primaarse teemana tegevussubjekti, aga nt olemasolulausete puhul lausealgulist lokatiivset määrust ning sihiliste umbja üldisikuliste lausete puhul tegevusobjekti. Lause fookuses asuvat tegevussubjekti käsitlen fookusena, mitte primaarse teemana. 
Tabel 1. Tunnused, mille alusel olen konverbitarindi inforolli kirjeldanud.

\begin{tabular}{|c|c|}
\hline Tunnused & Kategooriad \\
\hline Tarindi baasfunktsioon & AEG, KAASNEMINE \\
\hline Tarindi lisafunktsioon & $\begin{array}{l}\text { PUUDUB, MÖÖNDUS, PÕHJUS, OTSTARVE, } \\
\text { TINGIMUS, TULEMUS, TÄPSUSTUS, VAHEND, } \\
\text { VASTANDUS, VIIS }\end{array}$ \\
\hline Tarindi asukoht & Ees, sees, järel \\
\hline Konverbi asukoht & Esimene, viimane, üksi, muu \\
\hline Konverbi infiniitvorm & des-, maks-, mata-vorm \\
\hline Tarindis sisalduv klaus & $\begin{array}{l}\text { Kõrvallause, kiillause, } d a \text {-tarind, } \\
m a \text {-tarind, } m a s \text {-tarind, } v a t \text {-tarind, } \\
n u d \text {-tarind, } t u d \text {-tarind } v \text {-tarind, puudub }\end{array}$ \\
\hline $\begin{array}{l}\text { (Järel)tarindit } \\
\text { põhilausega siduv } \\
\text { konnektiiv või asesõna }\end{array}$ & $\begin{array}{l}\text { ise, nii, niimoodi, niiviisi, nõnda, } \\
\text { samal ajal, sealjuures, seega, seejuures, } \\
\text { sel viisil, sellega, selle kohta, selleks, } \\
\text { seepärast, siis, siiski, ühtlasi, üksteise, } \\
\text { isikulised asesõnad, puudub }\end{array}$ \\
\hline $\begin{array}{l}\text { Tarindit põhilausest } \\
\text { eraldav kirjavahemärk }\end{array}$ & Koma, mõttekriips, punkt, sulud, puudub \\
\hline Tarindi pikkus (sõnades) & $1-43$ \\
\hline Konverbi laiendite arv & $0-4$ \\
\hline Tarindit fookustav laiend & $\begin{array}{l}\text { aga, ainult, alles, gi-/ki-liide, ikka, isegi, } \\
\text { jälle, ju, juba, just, ka, koguni, küll, } \\
\text { kummatigi, mõistagi, muidugi, nimme, } \\
\text { nüüd, ometi, peamiselt, tõesti, täiesti, } \\
\text { vaid, veel, õieti, üksnes, puudub }\end{array}$ \\
\hline $\begin{array}{l}\text { Tarindiga seotud } \\
\text { kaassõna } i l m a^{4}\end{array}$ & ilma, puudub \\
\hline $\begin{array}{l}\text { Tarindi infostruktuuriline } \\
\text { roll }\end{array}$ & $\begin{array}{l}\text { Omaette infoüksus, raamistav teema } \\
\text { (selle all-liigina kontrastiivne teema), } \\
\text { reema taustaosa, fookus }\end{array}$ \\
\hline
\end{tabular}

4 See tunnus puudutab ainult mata-tarindit. 
Infoüksuse reemale eelnevat osa, mis pole primaarne teema, käsitlen sekundaarse teemana, mille liigina eristan raamistavat ja kontrastiivset teemat kui kaht konverbitarindile omast inforolli. Raamistav teema on sekundaarne teema, mis pakub orientiiri ülejäänud infoüksuse vastuvõtmiseks ja tõlgendamiseks ning toimib tavaliselt määrusena. Kontrastiivne teema on sekundaarne teema, mis on millelegi vastandatud või esile tõstetud, aga ei toimi lause põhifookusena. Seejuures käsitlen kontrastiivse teemana kõiki vastandatud või esile tõstetud sekundaarseid, sh raamistavaid teemasid. Sekundaarsed teemad, mis pole ei raamistavad ega kontrastiivsed, on näidetes tähistatud lihtsalt sekundaarse teemana, täpsemat liiki eristamata.

Fookusena käsitlen kogu infoüksust või infoüksuse osa. Fookusena võib toimida 1) kogu infoüksus, mis ei sisalda teema-reema jaotust ja mille ükski osa pole ülejäänu suhtes esile tõstetud, 2) kogu reema, mille ükski osa pole ülejäänu suhtes esile tõstetud, või 3) reema osa, mis on ülejäänud reema suhtes esile tõstetud. Reema taustaosana käsitlen fookusest üle jäänud reemat, st reema osa, mille suhtes mõni teine reema osa on esile tõstetud.

Infoüksuse, fookuse, primaarse, raamistava ja kontrastiivse teema piire tähistan nurksulgude abil, millele järgnev lühend - vastavalt IÜ, F, PT, RT või KT - märgib moodustaja inforolli. Reema taustaosa pole näitelausetes tähistatud: kogu infoüksus peale teema(de) ja fookuse on mõistetav reema taustaosana. Fookus on tähistatud infoüksustes, mis sisaldavad ka reema taustaosa. Näitelausetes, mis ei sisalda reema taustaosa, on fookus esile tõstmata ja mõistetav kogu reemana.

Et siinne artikkel keskendub konverbitarindi kui terviku inforollile ehk välimisele infostruktuurile, pole näitelausetes märgitud konverbitarindi sisemist infostruktuuri, v.a erandjuhul millegi esiletoomiseks.

\section{Konverbitarindi inforollid}

Järgnevas annan ülevaate konverbitarindi inforollidest ning nende seosest struktuuritunnuste ja semantilise funktsiooniga. Näitan, et konverbitarind võib toimida nii omaette infoüksusena kui ka moodustada põhilausega ühise infoüksuse, täites raamistava teema, fookuse või reema taustaosa rolli. 


\subsection{Inforoll ja sõnajärg}

Konverbitarindi inforoll seostub tihedalt sõnajärjega. Konverbialguline tarind kaldub toimima omaette infoüksusena (13) ning konverbilõpuline ja ühesõnaline tarind moodustama põhilausega ühise infoüksuse, mispuhul tarindi täpne roll infoüksuses oleneb suuresti tarindi asukohast: eestarind toimib tavaliselt raamistava teemana (14), sisetarind reema taustaosana (15) ja järeltarind fookusena (16).

(13) $\left[[\text { Tema sõnul }]_{\mathrm{RT}} \text { olevat [president Tudjman }\right]_{\mathrm{PT}}$ surres [ta kätt surunud $\left.]_{\mathrm{F}}\right]_{\mathrm{IU}}$,

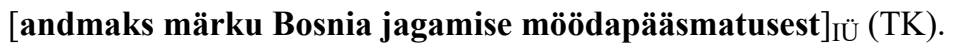

(14) ja [[seda öeldes $]_{R T}$ paistis [vanaema ise $\left.]_{P T}[\text { nii väike }]_{\mathrm{F}}\right]_{\mathrm{IUU}}($ ILU).

(15) $[\text { [NSVL rahvasaadikute valimisel }]_{\mathrm{RT}}$ sidusid [mitmed avaliku elu tegelased $]_{\mathrm{PT}}$ probleemisse süvenemata end $\left.[\text { katteta lubadustega }]_{\mathrm{F}}\right]_{\mathrm{IU}}(\mathrm{AJA})$.

(16) $\left[[\text { Kohati }]_{\mathrm{RT}} \text { muutub }[\mathrm{käik}]_{\mathrm{PT}}[\text { madalaks }]_{\mathrm{F}}\right]_{\mathrm{IU}}$, [[ta $]_{\mathrm{PT}}$ lööb pea [vastu lage $]$

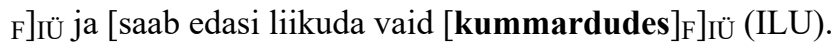

Sõnajärjelisi seaduspärasid täiendavad teiste teguritega seotud seaduspärad, mis piiravad ühtlasi sõnajärjeliste seaduspärade kehtivusala. Põhilausest vahemärgiga eraldatud tarind kaldub toimima omaette infoüksusena (17). Konverbitarind (täpsemalt selle konverbi sisaldav osa), mis ei asu sõnajärjeliselt komplekslause lõpus, kuid asub infoüksuse fookuspositsioonis või on esile tõstetud, toimib fookusena (18). Eestarind, mis on esile tõstetud või tähenduselt millelegi vastandatud, aga ei paikne infoüksuse fookuspositsioonis, toimib kontrastiivse teemana (19). Tarindi sees paikneva konverbiga tarind, mis moodustab ühtse infoüksuse, toimib omaette infoüksusena (20). Tarindi sees paikneva konverbiga tarind (täpsemalt selle konverbi sisaldav osa), millele järgnev laiend toimib omaette infoüksusena, kuulub komplekslause reema taustaossa või toimib fookusena (21).

(17) $\left.\left[[\text { Tondi lõpp-peatusele lähenedes }]_{\mathrm{RT}} \text { tõusis [tüdruk }\right]_{\mathrm{PT}}[\text { varakult }]_{\mathrm{F}}\right]_{\mathrm{IU}}$ ja [läks [ukse juurde seisma $\left.]_{\mathrm{F}}\right]_{I \cup ̈}$, [ise kordagi valge auto poole vaatamata $]_{I U}(I L U)$.

(18) $\left[[\text { kes oskab, }]_{P T} \text { võib neid ka [varem nägemata }\right]_{\mathrm{F}}$ lugeda $]_{\mathrm{IU}}(\mathrm{ILU})$. 
(19) $\left[[\text { Desmondile }]_{\mathrm{ST}} \text { ei tulnud [sellise teema käsitlemine }\right]_{\mathrm{PT}}$ [erilise üllatusena $\left.]_{\mathrm{F}}\right]_{\mathrm{IU}}$, sest [juba [villasse sisenedes $]_{\mathrm{KT}}$ oli $[\mathrm{ta}]_{\mathrm{PT}}$ imestuse ja õudusega märganud seintel [mitmesuguseid maale ja litograafiaid vampiiridest] $]_{\text {IÜ }}$ (ILU).

(20) [[Kahekümne aasta vältel, 1960-1980, $]_{\mathrm{RT}}$ tuli [plaadikombain] $]_{\mathrm{PT}}$ kasutusele [peaaegu kõigis maailma kohvikutes $\left.]_{\mathrm{F}}\right]_{\mathrm{IU}}$, [teenis usinasti [kliente] $\mathrm{F}]_{\mathrm{IU}}$ ja $\left[[\mathrm{kadus}]_{\mathrm{F}} \text { siis }\right]_{\mathrm{IU}}$, [andes koha $\left.[\text { videole }]_{\mathrm{F}}\right]_{\mathrm{IU}}$, [oma eluajal sisse astumata Nõukogude Liitu] IÜ (ILU).

(21) , ,[[Nad $]_{\mathrm{PT}}$ jäävad $]_{\mathrm{IUU}}$, “ [ütles [peremees $]_{\mathrm{PT}}[$ Effu ja vana paksu naisega tagasi tulles $\left.]_{\mathrm{F}}\right]_{\mathrm{IU}},{ }_{-}[\mathrm{kes}]_{\mathrm{PT}}$ pidi $[\mathrm{kokk}]_{\mathrm{F}}$ olema $]_{\mathrm{IU}}(\mathrm{ILU})$.

Nagu eespool mainitud, on inglise keeles käsitletud infoüksuse kirjaliku indikaatorina kirjavahemärke (Chafe 1988, Moore 2016). Kirjavahemärgistus varieerub keeliti ja konstruktsiooniti. Kuigi eesti konverbitarindi vahemärgistamise reeglid ei olene otseselt infotasandist, vaid sõnajärjest (Erelt 2019: 151-152), seostub vahemärgistus ka infotasandiga. Esiteks võib infotasand mõjutada vahemärgistust seal, kus reeglid jätavad keelekasutajale vabaduse (vt Erelt 2019: 152). Teiseks seostub infotasand vahemärgistusega sõnajärje ja sellel põhinevate reeglite kaudu. Et vahemärgistuse ja infotasandi seose laad pole siiski päris selge, seostan infotasandit järgnevas eelkõige sõnajärjega. Infotasandi otseseosele vahemärgistusega pööran tähelepanu seal, kus see on silmatorkavalt oluline (29-30).

Järgmiseks annan täpsema ülevaate konverbitarindi inforollidest ning nende seosest struktuuritunnuste ja semantilise funktsiooniga.

\subsection{Omaette infoüksus}

Tüüpiline omaette infoüksusena toimiv tarind on konverbialguline ja paikneb põhilause järel. Põhilause moodustab ühe infoüksuse, mille fookuspositsioon paikneb enamasti vahetult konverbitarindi ees, ja konverbitarind moodustab teise infoüksuse, mis toimib sageli kogu tarindit hõlmava lausefookusena (Lambrecht 2000, Lindström 2017: 545; 22-24). Juba varem on tähele pandud, et maks-tarind, mis esineb tavaliselt konverbialgulise järeltarindina, kaldub põhilausest intonatsiooniliselt eralduma (Erelt 2017c: 799). 
Põhilause infoüksusel ja konverbitarindi infoüksusel on tavaliselt ühine, tarindis implitsiitne tegevussubjekt ja primaarne teema, mis toimib kahe infoüksuse diskursuseteemana (22-24).

(22) Sest [[kuulu järgi $]_{\mathrm{RT}}$ leidnud [viimane $]_{\mathrm{PT}}$ aastate eest talu [tühjana ja

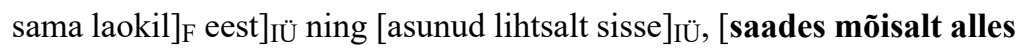
tagantjärele pidamisloa $]_{I U ̈}$ (ILU).

(23) $\left[[0 \tilde{O} l 1 u]_{\mathrm{PT}} \text { on }[\text { firma }]_{\mathrm{F}}\right]_{\mathrm{IUU}}$, [[mis $]_{\mathrm{PT}}$ sirgeselgse järjekindlusega pühendub [eesti eksiilkirjanduse publitseerimisele $]_{\mathrm{F}}$, [otsimata sealjuures majanduslikku tuge millegi kergemakaalulise ja populaarse trükkimisest $]_{I U ̈}$ (AJA).

(24) $\left.\left[[\text { Belgia sadamatöölised }]_{\mathrm{PT}} \text { alustasid esmaspäeval [ööpäevast streiki }\right]_{\mathrm{F}}\right]_{\mathrm{IU}}$ [väljendamaks oma pahameelt plaanidele avada kaupade käsitlemine konkurentsile $]_{I U ̈}(\mathrm{TK})$.

Konverbialguline ees- ja sisetarind on harvemad konstruktsioonid kui konverbialguline järeltarind. Konverbialguline eestarind (25-26) seostub põhilausega ühest küljest nagu raamistav teema ülejäänud infoüksusega: see pakub põhilause vastuvõtmiseks kasulikku konteksti ning tavaliselt järgneb eestarindile inverteeritud põhilause nagu tüüpilisele raamistavale teemale (25). Eestarindi ja põhilause seose tihedusele viitab ka asjaolu, et ilma põhilause abil mõistetava tegevussubjektita oleks eestarind tähenduselt poolik. Teisest küljest eristub konverbialgulise tarindi sündmus põhilause sündmusest selgemalt kui konverbilõpulise tarindi sündmus (vt jaotis 3.3.1)). Konverbialguline eestarind sisaldab enamasti uut, ennustamatut infot ja väljendab suhteliselt terviklikku sündmust. Tähenduslikku iseseisvust silmas pidades käsitlen konverbialgulist eestarindit omaette infoüksusena, mis on põhilause infoüksusega siiski tihedalt seotud.

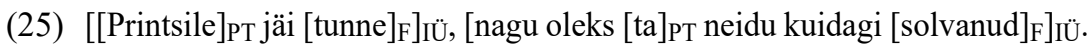
[Soovides vabandada ja asjasse selgust tuua $]_{\mathrm{IU}}$, [jooksis $[\text { ta }]_{\mathrm{PT}}[$ Tuhkatriinule järele $\left.]_{\mathrm{F}}\right]_{\mathrm{IU}}(\mathrm{AJA})$.

(26) ,[[Ebaausad inimesed $]_{P T}$ pole oma asjadega $\left.[\text { nii hooletud }]_{\mathrm{F}}\right]_{\mathrm{IU}}$.“ “ $[$ Andmata mulle aega toibuda sellest ebaharilikust komplimendist $]_{I U U}$, [[leitnant $]_{\mathrm{PT}}$ tõsines $]_{\mathrm{IU}}$. (ILU) 
Konverbialguline sisetarind paikneb kiilüksusena põhilause sees, misjuures kahe vaheliti paikneva infoüksuse osad kalduvad järjestma nii: 1. põhilause infoüksuse teema(d) ja reema taustaosa, 2. konverbitarindi infoüksus, 3. põhilause infoüksuse fookus (27-28). Konverbialguline sisetarind lisab sissepõikena infot, mida on otsustatud esitada enne pooleli oleva infoüksuse põhiinfot.

(27) Ja [[tõlkis $]_{\mathrm{KT}}[\text { seda }]_{\mathrm{ST}}$ suurepärase meisterlikkuse, elegantsiga - [saavutades külalistega väga hea kontakti $\left.]_{I U ̈}-[\mathrm{Oleg} \text { Mutt }]_{\mathrm{F}}\right]_{I U ̈}(\mathrm{AJA})$.

(28) $\left[[k e d a]_{S T}[\operatorname{võimsad~õhupuhurid~}]_{\mathrm{PT}}-[\text { hoidmaks neid eemal võitjast }]_{\mathrm{IU}}-\right.$ [jalust maha paiskasid] $\left.]_{\mathrm{F}}\right]_{\mathrm{IU}}(\mathrm{TK})$.

Konverbilõpuline järeltarind, mida eraldab põhilausest kirjavahemärk, toimib tavaliselt omaette infoüksusena (29-30). Kontekstis, kus norming vahemärki ei nõua ja tavaliselt seda ei kasutata, võib vahemärk siiski täita infoüksusi eraldavat funktsiooni. Vahemärgiga eraldatud järeltarindile on iseloomulikud konnektiivid ja korrelaadid, nt sealjuures, seega ja siis, mis viitavad tagasi eelnevale kontekstile, sageli põhilausele (29; jaotis 3.4).

(29) $\left[[\text { Marvi }]_{\mathrm{PT}}[\text { sobras }]_{\mathrm{F}} \text { neis }\right]_{\mathrm{IU}}$, [valis $]_{I U ̈}$, [ise sealjuures rõõmsameelselt juhtumeid kirjeldades $]_{I U}$ (ILU).

(30) $\left[[\text { Oma jao }]_{\mathrm{ST}} \text { said ka }[\text { idanaabrid }]_{\mathrm{F}}\right]_{\mathrm{IÜ}},\left[[\mathrm{kes}]_{\mathrm{PT}}\right.$ olevat peaasjalikult

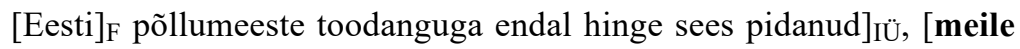
midagi vajalikku vastu andmata $]_{I U ̈}(\mathrm{AJA})$.

Kirjavahemärk ei pruugi siiski eraldada infoüksusi, vaid võib täita mingit muud ülesannet. Nt vahemärgiga eraldatud tarind, mis on põhilause fookustatud moodustajaga rinnastatud või sellele alistatud, ei toimi mitte omaette infoüksusena, vaid pigem fookuse osana (31).

(31) [Kaduda jäljeta, jäägitult, tagasi pöördumata $]_{I U}-[\text { milline õndsus }]_{I U ̈,}$ [võrreldes armsate suguvendade loodud keskkonnaga su ümber]IÜ (ILU).

Tarindi sees asuva konverbiga tarind, mis moodustab infotasandil terviku, toimib omaette infoüksusena (32). 
(32) $\left.\left[[\text { Mehed }]_{\mathrm{PT}} \text { hoidsid neil [kätest }\right]_{\mathrm{F}}\right]_{\mathrm{IU}}$ ja [kappasid võidu [mööda libedat parketti $\left.]_{\mathrm{F}}\right]_{\mathrm{IU}}$, [ise karjudes ,hii-haa! hii-haa!“‘] $]_{\mathrm{IU}}(\mathrm{ILU})^{5}$.

Tarindi sees asuva konverbiga tarind, mis sisaldab omakorda klausi, moodustab tavaliselt mitu infoüksust (33).

(33) $\left.\left[[\text { kes }]_{\mathrm{PT}} \text { kullast maja akendel [itsitasid }\right]_{\mathrm{F}}\right]_{\mathrm{IU}}$ ja [kõige häbitumal kombel [oma ihuvorme välgutasid $\left.]_{\mathrm{F}}\right]_{\mathrm{IU}}$, [seejuures koguni iseäraliste kõverpeeglite abi kasutades $]_{I U ̈},\left[[\mathrm{mis}]_{\text {PT }}\right.$ keha patupaiku [suurendasid ja hoopis loomuvastaseks muutsid $\left.]_{F}\right]_{I U ̈}$ (ILU).

Kuigi enamasti toimib konverbialguline tarind omaette infoüksusena, leidub konverbialgulisi tarindeid, mis moodustavad pigem põhilausega ühise infoüksuse. Lühikest eestarindit, mis täidab lokaliseerivat, nt AJA (baas)funktsiooni ja mida ei eralda põhilausest vahemärk, võib tõlgendada raamistava teemana $(34,10)$. Konverbialgulist järeltarindit, milleta põhilause on infotasandil poolik, võib tõlgendada hoolimata vahemärgist fookusena (35).

(34) $\left[[\text { Lahkudes Maia poolt }]_{\mathrm{RT}} \text { oleks }[\mathrm{ta}]_{\mathrm{PT}} \text { peaaegu }[\text { peeglisse sülitanud }]_{\mathrm{F}}\right]_{\mathrm{IU}}$ (ILU).

(35) $\left.\left[[\text { Kohtus }]_{\mathrm{RT}} \text { on tehtud otsuseid, [kontrollimata kõiki materjale }\right]_{\mathrm{F}}\right]_{\mathrm{IU}}$ (ILU).

Inforoll seostub semantilise funktsiooniga: igal semantilisel funktsioonil on iseloomulik(ud) inforoll(id), mida seda funktsiooni kandev konverbitarind tavaliselt täidab. Funktsioonid, mida täitev tarind kaldub toimima omaette infoüksusena, on KAASNEMISE baasfunktsioon (näited 32, 33), PÕHJUSE (25), TULEMUSE (27), TÄPSUSTUSE (36), VASTANDUSE (30) ja OTSTARBE lisafunktsioon (29). Väärib tähelepanu, et ka teised konstruktsioonid, mille abil neid funktsioone väljendatakse, toimivad tavaliselt omaette infoüksusena: KAASNEMISE, TULEMUSE, TÄPSUSTUSE ja VASTANDUSE funktsiooniga konverbitarindit saab parafraseerida rindosalause abil (Erelt 2017: 656-661), PÕHJUSE (Erelt 2017: 719-720) ja

5 Konverbiga seotud laiendit ise on käsitletud ka tarindivälisena (Erelt 2017: 812). Siin käsitlen seda tarindi osana, sest see võib paikneda ka tarindi sees (nt .. karjudes ise: ..) (vt ka Simmul 2017: 38). 
OTSTARBE (Erelt 2017: 723-724; 801) funktsiooniga tarindit järgneva määruslause abil. Selle põhjal võib arvata, et nimetatud semantilised funktsioonid on suhteliselt lauselised või et neil on vähemalt lauseline esinemiskuju, mis avaldub mh konverbitarindi vormis.

(36) [[Laudaaeg] $]_{\mathrm{PT}}$ on rangeks eksamiks eelkõige [majandite, brigaadide ja farmide juhtidele $\left.]_{\mathrm{F}}\right]_{I \cup ̈}$ [ [kontrollides nende oskust tööd korraldada $]_{I U ̈}$ (AJA).

\subsection{Põhilausega ühine infoüksus}

Selles jaotises annan ülevaate tarinditest, mis moodustavad põhilausega ühise infoüksuse, toimides selle raamistava (sh kontrastiivse) teema, reema taustaosa või fookusena.

\subsubsection{Raamistav teema}

Konverbilõpuline või ühesõnaline eestarind toimib enamasti raamistava teemana (37-38), mis väljendab infoüksuse tuumosa konteksti (Chafe 1976: 50-51, Jacobs 2001: 655-657, Krifka \& Féry 2008: 129). Raamistava teema roll võib olla lihtsalt orienteeriv (37) või rangemalt piiritlev (38).

(37) $\left.\left[[\mathrm{Ma}]_{\mathrm{PT}} \text { imestasin [oma kujutluse üle }\right]_{\mathrm{F}}\right]_{\mathrm{IÜ}}$, et [[tulekahjust rääkides $]_{\mathrm{RT}}$ pidas [naine $]_{\mathrm{PT}}$ silmas $\left.[\text { leeke ja kuma }]_{\mathrm{F}}\right]_{\mathrm{IU}}$ (ILU).

(38) $\left[[\text { Autod }]_{\mathrm{PT}} \text { aina }[\text { tulevad ning lähevad }]_{\mathrm{F}}\right]_{\mathrm{IU}} \mathrm{ja}\left[[\text { ilma kontrollimata }]_{\mathrm{RT}}\right.$ ei sõida neist üle piiri [ükski] $]_{\mathrm{F}} \mathrm{IÜ}(\mathrm{AJA})$.

Raamistav tarind, mis on esile tõstetud või millelegi vastandatud, aga ei paikne infoüksuse fookuspositsioonis (vrd näide 45), toimib kontrastiivse teemana, tuues infoüksuse mitme võimaliku raamistiku seast esile ühe (vt ka Krifka 2007: 47-48). Näites 39 on eestarind .. tungides kontrastiivne ja üldlaiendi alles abil esile tõstetud. Infoüksuse põhifookusena toimib seejuures pigem üksuslõpuline moodustaja madalaid vundamendijäänuseid. 
(39) $\left.\left[[\text { Seeasemel }]_{R T} \text { lokkas igal pool [võsa }\right]_{\mathrm{F}}\right]_{I U ̈ \text {, }}$ [alles [päris sinna sisse tungides $]_{\mathrm{KT}}$ nägi $[R]_{\mathrm{PT}}$ maapinnal [madalaid vundamendijäänuseid $\left.]_{\mathrm{F}}\right]_{\mathrm{IÜ}}$ (ILU).

Raamistavat ja ühtlasi kontekstualiseerivat inforolli täidavad tavaliselt konverbitarindid, mis kannavad lokaliseerivat semantilist funktsiooni, enamasti AJA baasfunktsiooni (37), TINGIMUSE lisafunktsiooni (38) või AJA baasfunktsiooni ja VAHENDI lisafunktsiooni (39).

\subsubsection{Reema taustaosa}

Konverbilõpuline või ühesõnaline sisetarind kuulub tavaliselt põhilausega ühise infoüksuse reemasse ja toimib selle taustaosana, nagu kaks rinnastatud konverbitarindit näites 40 .

(40) $\left.\left[[\text { Kaks neist }]_{\mathrm{PT}} \text { tulid [autost välja }\right]_{\mathrm{F}}\right]_{\mathrm{IU}}$ ja [astusid kiirustamata, hindava pilguga ümbrust silmitsedes [ukse poole $\left.]_{\mathrm{F}}\right]_{\mathrm{IU}}$ (ILU).

Kuivõrd eesti keeles kalduvad verbiga tihedamalt seotud järellaiendid asuma verbist kaugemal kui nõrgemalt seotud laiendid (Sahkai 1999: 31), ongi konverbitarindi süntaktilise funktsiooni seisukohast ootuspärane asend vahetult verbi järel, tihedamalt seotud laiendite ees. Asjaolu, et tavaliselt asub konverbitarind siiski põhilause ees või järel, mitte sees (Simmul 2020: 228), seostub ilmselt struktuuriga: sekundaartarindina kaldub konverbitarind esinema põhilause infoüksuse perifeerias või sellest väljaspool (Sahkai 1999: 32). Konverbilõpuline või ühesõnaline sisetarind on aga konverbitarindi kõige tihedamalt põhilausesse integreeritud ja selle poolest nominaalse määrusega sarnanev esinemiskuju.

Reema taustaosa roll on iseloomulik vIISI lisafunktsiooniga matatarinditele (40), mille seas leidub kõigist funktsiooni ja infiniitvormi kombinatsioonidest enim ühesõnalisi tarindeid. Peale selle on reema taustaosa roll suhteliselt levinud kõigi lisafunktsioonide puhul, mille tüüpilisim inforoll on fookus. Seega on reema taustaosa roll üldjoontes omane samasugustele põhilause sündmust täpsustavatele sündmustele kui fookuseroll (vt jaotis 3.3.3). 


\subsubsection{Fookus}

Konverbilõpuline ja ühesõnalise järeltarind toimivad tavaliselt infoüksuse fookusena, misjuures põhilause väljendab sama infoüksuse teemat ja reema taustaosa (41).

(41) [[Pagasiruumi ja bensiinipaagi luuki] $]_{\mathrm{PT}}$ saab avada ka [autost väljumata $\left.]_{\mathrm{F}}\right]_{\mathrm{IU}}(\mathrm{AJA})$.

Fookusena toimivad ka sellised konverbilõpulised sisetarindid, mis on esile tõstetud või millele järgneb fookustamata (42) või omaette infoüksusena toimiv (43) põhilause element; selliste konverbialguliste järeltarindite konverbi sisaldav osa, mille moodustaja toimib omaette infoüksusena (44); ja infoüksuse fookuspositsioonis asuvad eestarindid (45).

(42) $\left[[\text { Ostetud marju }]_{\mathrm{KT}} \text { ei tasuks siiski [ilma pesemata }\right]_{\mathrm{F}}$ süüa $]_{\mathrm{IUU}}(\mathrm{AJA})$.

(43) $\left[[\text { Mai }]_{\mathrm{PT}} \text { tähendas }[\text { kaheldes }]_{\mathrm{F}}\right]_{I U ̈}:$,[Tuleva ehk [tiid piti $\left.]_{\mathrm{F}}\right]_{I U ̈}$... ?“

(44) $\left.\left[[\text { Nüüdne kolmas koht }]_{\mathrm{PT}} \text { tegi heameelt aga kindlasti [seepärastki }\right]_{\mathrm{F}}\right]_{\mathrm{IU}}$, et [tuli [trotsides reisiväsimust $\left.]_{\mathrm{F}}\right]_{\mathrm{IU}}$ ([täpsemalt küll [magamatust $\left.]_{\mathrm{F}}\right]_{\mathrm{IU}}$, $\left[[\mathrm{mis}]_{\mathrm{PT}} \text { meie maal öösiti sõites üldse [haruldus }\right]_{\mathrm{F}}$ pole $\left.]_{\mathrm{IU}}\right)(\mathrm{AJA})$.

(45) [[Millisele seadusele toetudes $]_{\mathrm{F}}$ hakkavad toimuma IL poolt väljakuulutatud alternatiivvalimised $]_{\mathrm{IU}}$ ?

Fookustatud on tavaliselt ka täiendi või seotud määrusena toimiv maks-järeltarind (46-47; Erelt 2017c: 801-803), mis ei mahu rangelt võttes konverbitarindi kui vaba laiendi määratluse alla (Haspelmath 1995: 3). Siin käsitlen sellist maks-tarindit siiski konverbitarindina: vormilt ja tähenduselt sarnaneb see vaba laiendina toimiva makstarindiga niivõrd, et konstruktsioonide lahus hoidmine ei tundu inforolli seisukohast otstarbekas. Täiendi või seotud laiendina toimivale makstarindile omast fookustatust võib seletada sellega, et selline maks-tarind laiendab tavaliselt põhilause kõige raskemat ja ühtlasi põhilause lõpus paiknevat moodustajat, mis võib olla koos maks-tarindiga fookustatud (46).

(46) $\left.\left[[\text { Spetsialiseerumine }]_{\mathrm{PT}} \text { on [ainus tee jõudmaks tippu }\right]_{\mathrm{F}}\right]_{\mathrm{IU}}(\mathrm{TK})$. 
(47) [[Reorganisatsioon $]_{\mathrm{PT}}$ on mõeldud [kinnitamaks investoritele börsil noteeritud firmade usaldusväärsust $\left.]_{\mathrm{F}}\right]_{\mathrm{IU}}(\mathrm{TK})$.

Funktsioonid, mida täitev konverbitarind toimib tavaliselt fookusena, on $\operatorname{VIISI}^{6}(43,45)$ ja MöÖNDUSE (41) lisafunktsioon ning KAASNEMISE baasfunktsioonile liituv vAHENDI lisafunktsioon (44). Neid funktsioone kandvad tarindid väljendavad põhilause situatsiooni sündmuslikku komponenti, mis paikneb sageli infoüksuse lõpus ja esitab selle kõige ennustamatumat infot.

\subsection{Konverbialgulisus/-lõpulisus kui infotasandi konstruktsioon}

Konverbialgulise ja -lõpulise tarindi inforoll erinevad: konverbialguline tarind kaldub toimima omaette infoüksusena, aga konverbiIõpuline tarind põhilausega ühise infoüksuse osana. Selles jaotises selgitan konverbialgulise ja -lõpulise tarindi erinevusi lähemalt. Ühesõnaline ja tarindi sees asuva konverbiga tarind eraldi vaatlusele ei tule, aga üldjoontes võimenduvad nende puhul needsamad erinevused, mis eristavad konverbilõpulist ja -algulist tarindit. St ühesõnaline tarind kuulub tihedalt põhilausesse ja tarindi sees asuva konverbiga tarind on just kui tavamallist välja kasvanud konverbialguline tarind, mis koosneb sageli mitmest infoüksusest (33).

Konverbialguline tarind on keskmiselt üle kahe korra pikem kui konverbilõpuline tarind. Erinevus kehtib olenemata tarindi asukohast: nii konverbialgulise ees-, sise- kui ka järeltarindi keskmine pikkus ületab vastava konverbilõpulise tarindi pikkuse vähemalt kaks korda. Kummatigi ei tulene pikkuserinevus laiendite arvust: laiendeid on konverbialgulisel ja -lõpulisel tarindil enam-vähem ühepalju. Konstruktsioonide pikkuserinevus tuleneb laiendite pikkusest ja võimalik, et mingil määral ka tarindiga seotud üldlaiendite arvust. Märkimisväärselt eristub konverbialgulise ja -lõpulise tarindi laiendite struktuur: ligi 40\% konverbialgulistest tarinditest sisaldab vähemalt üht klausi (kõrvallauset, infiniittarindit või kiillauset; 25-26), aga konverbilõpuline tarind sisaldab klausi haruharva (alla 1\% tarinditest). Seda võib seletada sellega, et konverbialguline tarind sisaldab rohkem uut infot, mida väljendatakse

6 VIISI funktsiooniga mata-tarindil on fookus teine põhiroll reema taustaosa kõrval. 
sageli komplekssemate konstruktsioonide abil. Arvuliselt annab konverbialgulise ja -lõpulise tarindi tunnustest ülevaate tabel 2 .

Tabel 2. Konverbialgulise ja -lõpulise tarindi tunnused.

\begin{tabular}{l|r|r}
\hline Konverbi asukoht tarindis & \multicolumn{1}{|l}{ Alguses } & \multicolumn{1}{l}{ Lõpus } \\
\hline Arv (analüüsitud materjalis) & $931(52 \%)$ & $660(37 \%)$ \\
\hline Tüüpiline inforoll & Omaette infoüksus & Infoüksuse osa \\
\hline Keskmine pikkus sõnades & 6,9 & 3 \\
\hline Keskmine laiendite hulk & 1,3 & 1,2 \\
\hline Klausi sisaldavate tarindite hulk & $371(40 \%)$ & $6(1 \%)$ \\
\hline
\end{tabular}

Konverbialgulisel ja -lõpulisel tarindil leidub veel erinevusi. Näiteks esineb konverbialgulises järeltarindis suhteliselt sageli põhilausega seost loovaid konnektiive, korrelaate ja asesõnu (nt niisiis, samal ajal, seega, seejuures, seetôttu, nii, ise; 48).

(48) $\left.\left[[\text { mille tulemusena }]_{\mathrm{ST}}[\mathrm{see}]_{\mathrm{PT}} \text { omandab küll [kõik aatepoliitika hädad }\right]_{\mathrm{F}}\right]$

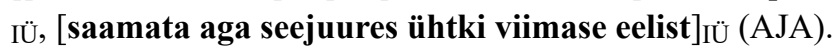

Sellised keelendid toovad esile konverbialgulise tarindi sündmuse ajalist vm seost põhilause sündmusega. Konverbilõpuline tarind ei vaja tavaliselt konnektiivset laiendit, sest ühe infoüksuse piires on vastav seos vaikimisi selge (49).

(49) $\left.[\text { Seisime minutikese [üksteise ümbert kinni hoides ja nuttes }]_{\mathrm{F}}\right]_{I U ̈}($ ILU).

Eksplitsiitse tegevussubjektiga konverbitarind ja kaassõnaga ilma seotud mata-tarind on konverbilõpuline (50-51). Et ei eksplitsiitse tegevussubjektiga tarind (Sahkai 2011: 16-17) ega ilma + mata-tarind ei väljenda mitte niivõrd iseseisvat sündmust, kuivõrd põhilause sündmuse komponenti, on mõlema konstruktsiooni tähendus kooskõlas konverbilõpulise malliga, mis lõimub tihedalt põhilausega.

(50) $\left.\left[[\text { Vilja küpsedes }]_{\mathrm{RT}} \text { muutub [valge piimmahl }\right]_{\mathrm{PT}}[\text { vesiseks }]_{\mathrm{F}}\right]_{\mathrm{IU}}(\mathrm{AJA})$.

(51) [[mis $]_{\mathrm{PT}}$ võimaldavad sellest raskusest üle saada [ilma kaasinimeste huve riivamata $\left.]_{\mathrm{F}}\right]_{\mathrm{IÜ}}(\mathrm{AJA})$. 
Eelnevat kokku võttes sisaldab konverbialguline tarind pikemaid ja lauselisemaid moodustajaid ning rohkem põhilausega seost loovaid konnektiive kui konverbilõpuline tarind. Eksplitsiitse tegevussubjektiga ja kaassõnaga ilma seotud tarindid on aga konverbilõpulised. Konverbialgulist ja -lõpulist malli ei erista üksnes vormitunnused. Konverbitarindi sõnajärg, sh konverbi asukoht, on ise funktsionaalne: konverbilõpuline sõnajärg väljendab tarindi tihedamat infoseost põhilausega kui konverbialguline sõnajärg. Seda ilmestab kahe konverbilõpulist tarindit sisaldava korpusnäite $(52,53)$ võrdlus kummagi näite järel esitatud teisendiga (52' ja 53'), kus konverb on tõstetud tarindi algusse. Tarind, mis toimib konverbilõpulisel kujul fookusena, toimib konverbialgulisel kujul omaette infoüksusena. Ühtlasi tõlgendub teisiti kogu komplekslause infostruktuur.

(52) $\left.\left[[\text { Aarne }]_{\mathrm{PT}} \text { sulges hetkeks [silmad }\right]_{\mathrm{F}}\right]_{\mathrm{IÜ}}$, [avas siis [jälle $\left.]_{\mathrm{F}}\right]_{\mathrm{IUU}}$, [astus tädi Idast mööda [teda kergelt õlast tõugates $\left.]_{\mathrm{F}}\right]_{I U ̈}$ (ILU).

(52') $\left.\left[[\text { Aarne }]_{\mathrm{PT}} \text { sulges hetkeks [silmad }\right]_{\mathrm{F}}\right]_{\mathrm{IÜ}}$, [avas siis [jälle] $\left.]_{\mathrm{F}}\right]_{\mathrm{IÜ}}$, [astus tädi Idast [mööda $\left.]_{F}\right]_{I U ̈}$, [tõugates teda kergelt [õlast $\left.]_{F}\right]_{I U ̈}$.

(53) $\left.\left[[\mathrm{Ta}]_{\mathrm{PT}} \text { vaatas uuesti [sõbrannade poole }\right]_{\mathrm{F}}\right]_{\mathrm{IÜ}}$. [[Need $]_{\mathrm{PT}}$ vadistasid edasi $\left.[\text { midagi märkamata }]_{\mathrm{F}}\right]_{\mathrm{IU}}$. (ILU)

$\left(53^{\prime}\right)\left[[\mathrm{Ta}]_{\mathrm{PT}} \text { vaatas uuesti }[\text { sõbrannade poole }]_{\mathrm{F}}\right]_{\mathrm{IÜ}}$. $\left[[\mathrm{Need}]_{\mathrm{PT}}\right.$ vadistasid [edasi $\left.]_{\mathrm{F}}\right]_{\mathrm{IÜ}}$, [märkamata midagi $]_{\mathrm{IÜ}}$.

Konverbi asukoht toimib infotasandil konstruktsioonina, vormi ja tähenduse vastavusena (Goldberg 1995). Konverbi asukoha funktsionaalsus võib seostuda kolme asjaoluga - kirjavahemärgistuse, verbialgulisuse ja omaette infostruktuuriga -, mis seostuvad tõenäoliselt ka omavahel.

Esiteks võib konverbi asukoha funktsionaalsus seostuda kirjutusviisiga: konverbialgulise tarindi iseseisvust infotasandil võib toetada asjaolu, et normingu ja keeletava alusel eraldatakse konverbialguline tarind põhilausest sagedamini komaga kui konverbilõpuline tarind. Teisalt võib infotasandi erinevus olla vanem kui komareeglid ja olla nende aluseks.

Teiseks võib süntaktilis-stilistiliselt olla oluline konverbi asukoht: verbialguline tarind tõstab sündmuse (teise sündmuse suhtes) 
teravamalt ja iseseisvamalt esile kui verbilõpuline tarind. Seesugusel viisil on Remmel (1963: 240-246) käsitlenud verbi asukohta kõrvallauses, vastandades verbialgulisi, tavaliselt teisel kohal asuva öeldisega kõrvallauseid kui „pealause kaaluga“ lauseid „tavalistele“ verbilõpulistele kõrvallausetele.

Kolmandaks võib konverbialgulise ja -lõpulise tarindi erinevus seostuda omaette infostruktuuri, täpsemalt tarindisisese fookuspositsiooni ning tuntud ja uue info vastandusega. Selgitan seda võimalust lähemalt.

Ajaloolis-tüpoloogiliselt on konverbitarind sageli kujunenud teonimefraasi määrusliku kasutuse põhjal (Koptjevskaja-Tamm 1993: 44, Haspelmath 1995: 49, Tikkanen 2001: 1121, Ylikoski 2003: 195). deskonverbi puhul on peetud tõenäoliseks võimalust, et see on kujunenud ajaloolise teonime määrusliku, nimelt inessiivse ja instruktiivse käändevormi põhjal (Univere 1970). mata-konverb on tõenäoliselt kujunenud selle ajaloolise teonime abessiivse käändevormi põhjal, mille põhjal on kujunenud kõik $m a$-infinitiivi tarindid (vt Erelt 2017c: 790-791). matakonverbi nimisõnalise lähtekuju kasuks räägib ka asjaolu, et sarnaselt nimisõnafraasiga võib mata-tarind laiendada kaassõna (ilma).

Eeldades, et eesti konverbitarind on kujunenud nimisõnafraasist, võib arvata, et tarindi esmakuju on nimisõnafraasile omaselt tuumalõpuline, misjuures fraas tervikuna toimib suurema infoüksuse osana, nii et selles ei esildu omaette fookust ega infostruktuuri. Tarindi konverbialguline kuju on selle käsitusviisi alusel pidanud kujunema fraasi edasise grammatiseerumise, süntaktilise klausistumise ja infostruktuurilise iseseisvumise käigus. Tarind on hakanud väljendama iseseisvamat sündmust ja viitama uutele referentidele, mis on hakanud paigutuma tarindi lõppu, kujundades välja tarindisisese fookuspositsiooni ja infostruktuuri. Ühtlasi on konverb hakanud paigutuma tarindi algusse kui lõpust tähtsuselt ja silmapaistvuselt järgmisse positsiooni. Kirjeldatud käsitusviisi alusel põhineb konverbilõpuline mall ajaloolise nimisõnafraasi morfosüntaksil, konverbialguline mall aga infostruktuuril, eelkõige uue info esiletõstmisel.

Ülal kirjeldatuga sarnasel viisil on Lindström (2006: 886) kirjeldanud osa kõrvallausete (relatiivlause ning kui-algulise aja- ja tingimuslause) infostruktuuri: uut infot väljendava kõrvallause lõpus paikneb uuele infole viitav moodustaja, ainult tuntud infot väljendav lause on aga verbilõpuline. 
Nii konverbitarindi kui ka mõne varem käsitletud konstruktsiooni uurimise tulemused tõstavad esile võimaluse, et verbialguline klaus, mis sisaldab omaette fookuspositsiooni, on lauselisem kui verbilõpuline klaus. Verbi asukoha seos lauselisusega võib olla üldine, mitmesuguseid klause hõlmav seaduspära.

\section{Kokkuvõte}

Konverbitarindi inforoll varieerub: osa tarindeid toimib omaette infoüksusena ja osa moodustab põhilausega ühise infoüksuse. Viimast laadi tarindid toimivad omakorda raamistava (sh kontrastiivse) teema, reema taustaosa või fookusena. Raamistava teemana toimiv konverbitarind piiritleb põhilause teise sündmuse suhtes, reema taustaossa kuuluv tarind väljendab põhilausesse integreeritud taust- või täiendsündmust, fookustatud tarind aga infoüksuse kõige ennustamatumat infot ning omaette infoüksusena toimiv tarind lisab põhilausega ühisel teemal täiendavat, ideeliselt terviklikku ja eraldi seisvat, ehkki seotud infot.

Konverbi inforoll seostub tihedalt nii konverbi kui ka tarindi asukohaga. See, kas tarind toimib omaette infoüksusena või moodustab põhilausega ühise infoüksuse, seostub eelkõige konverbi asukohaga: konverbialguline tarind toimib omaette infoüksusena, konverbilõpuline või ühesõnaline tarind moodustab põhilausega ühise infoüksuse. Konverbilõpulise ja ühesõnalise tarindi täpne inforoll oleneb eelkõige tarindi asukohast: eestarind toimib raamistava teemana, järeltarind fookusena ja sisetarind kuulub reema taustaossa.

Sõnajärjele lisaks mõjutavad konverbitarindi inforolli mitmesugused struktuurilised ja semantilised tegurid: kirjavahemärgistus, tarindi pikkus, konverbi laiendite pikkus ja struktuur, fookustavad üldlaiendid, põhilause kommunikatiivne tüüp, põhilause laiendid ning põhilause ja tarindi semantilise seose laad ja tihedus. Näiteks konverbilõpuline järeltarind, mis on põhilausest kirjavahemärgiga eraldatud, kaldub toimima omaette infoüksusena ning fookustava üldlaiendiga eestarind kaldub toimima kontrastiivse teemana ja sisetarind fookusena.

Iga semantiline funktsioon seostub konverbitarindi vormis mõne inforolliga. Lokaliseerivad funktsioonid - AEG, TINGIMUS ning AJA baas- ja VAHENDI lisafunktsiooni kombinatsioon - seostuvad raamistava teema rolliga. Funktsioonid, mida kandev tarind täpsustab põhilause sündmust - VIIS, MÖÖNDUS ning KAASNEMISE baas- ja VAHENDI 
lisafunktsiooni kombinatsioon -, seostuvad reema (fookustatud) osa rolliga. Funktsioonid, mida kandev tarind väljendab põhilause sündmusega samaväärset kõrvalsündmust - KAASNEMINE, PÕHJUS, TULEMUS, TÄPSUSTUS, VASTANDUS, OTSTARVE ${ }^{7}-$, seostuvad omaette infoüksuse rolliga. Üldistades: (põhilause sündmusega võrreldes) suured sündmused toimivad tavaliselt raamistava teemana ja kontekstualiseerivad põhilause sündmust, väiksed sündmused toimivad tavaliselt reema osana ja täpsustavad põhilause sündmust ning põhilause sündmusega sama suured sündmused toimivad tavaliselt omaette infoüksusena ja asetuvad põhilause sündmuse kõrvale.

Infotasandil eristuvad konverbilõpulised (ja ühesõnalised) ning konverbialgulised (ja tarindi sees asuva konverbiga) tarindid. Konverbialgulised tarindid on pikemad, neil on komplekssema struktuuriga laiendid, neis leidub rohkem põhilausele viitavaid konnektiive ja asesõnu, nad on sagedamini kirjavahemärgiga eraldatud ega seostu eksplitsiitse tegevussubjektiga ega kaassõnaga ilma. Ühtlasi kalduvad konverbialgulised tarindid toimima omaette infoüksusena, misjuures neil on omaette fookus ja infostruktuur. Konverbilõpulise tarindi sõnajärg põhineb eelkõige (ajaloolisel) morfosüntaksil, aga konverbialgulise tarindi sõnajärge mõjutab rohkem infostruktuur.

Artiklis vaatlesin konverbitarindit kirjakeeles, kus infostruktuur avaldub eeskätt sõnajärjes. Et infostruktuuril on olulised foneetilised korrelaadid (Sahkai, Mihkla \& Kalvik 2015, Mihkla \& Sahkai 2017), väärivad edaspidi uurimist suulise keele konverbitarindid. Samuti puudutas artikkel mitut teemat, mis väärivad lähemat uurimist: konverbitarindi inforolli seos tarindi sisemise infostruktuuriga, süntaktilise ja semantilise funktsiooni seos inforolliga ning infostruktuuri seos verbi asukoha ja kirjavahemärgistusega.

\section{Tänusõnad}

Artikli valmimist on toetanud Euroopa Regionaalarengu Fond (Eesti-uuringute Tippkeskus) ja Eesti Teadusagentuur (projekt PRG341 „Pragmaatika grammatika kohal: subjektiivsus ja intersubjektiivsus eesti keele registrites ja tekstiliikides“).

7 Täpsemalt OTSTARBE-funktsioon, mida täidavad vaba laiendina toimivad maks-tarindid. 


\section{Allikaviited}

AJA = Eesti kirjakeele korpuse 1990-ndate aastate ajakirjandustekstide katkendite korpus. https://www.cl.ut.ee/korpused/kasutajaliides/index.php?lang=et.

ILU = Eesti kirjakeele korpuse 1990-ndate aastate ilukirjandustekstide katkendite korpus. https://www.cl.ut.ee/korpused/kasutajaliides/index.php?lang=et.

$\mathbf{T K}=$ Tasakaalus korpus. http://www.keeleveeb.ee/.

\section{Kirjandus}

Adamou, Evangelia, Katharina Haude \& Matrine Vanhove. 2018. Investigating information structure in lesser-known and endangered languages: An introduction. Evangelia Adamou, Katharina Haude \& Matrine Vanhove (toim.), Information structure in lesser-described languages: Studies in prosody and syntax (Studies in Language Companion Series 199), 1-14. Amsterdam: John Benjamins. https://doi. org/10.1075/slcs.199.01ada.

Amon, Marri. 2015. Initial and final detachments in spoken Estonian: A study in the framework of Information Structuring (Dissertationes philologiae estonicae Universitatis Tartuensis 16). Tartu: Tartu Ülikooli Kirjastus.

Asu, Eva Liina, Pärtel Lippus, Karl Pajusalu \& Pire Teras. 2016. Eesti keele hääldus (Eesti keele varamu II). Tartu: Tartu Ülikooli kirjastus.

Chafe, Wallace. 1976. Givenness, contrastiveness, definiteness, subjects, topics, and point of view. Charles N. Li (toim.), Subject and topic, 25-55. New York: Academic Press.

Chafe, Wallace. 1979. The flow of thought and the flow of language. Thomas Givon (toim.), Discourse and Syntax, 159-181. New York: Academic Press.

Chafe, Wallace. 1982. Integration and involvement in speaking, writing, and oral literature. Deborah Tannen (toim.), Spoken and written language: Exploring orality and literacy, 35-53. Norwood, NJ: Ablex.

Chafe, Wallace. 1988. Punctuation and the prosody of written language. Written Communication 5. 395-426. https://doi.org/10.1177/0741088388005004001.

Ebert, Cornelia. 2009. Quantificational topics - A scopal treatment of exceptional wide scope phenomena (Studies in Linguistics and Philosophy 86). Berlin: Springer.

Erelt, Mati. 2017a. Sissejuhatus süntaksisse. Mati Erelt \& Helle Metslang (toim.), Eesti keele süntaks (Eesti keele varamu III), 53-89. Tartu: Tartu Ülikooli kirjastus.

Erelt, Mati. 2017b. Liitlause. Mati Erelt \& Helle Metslang (toim.), Eesti keele süntaks (Eesti keele varamu III), 647-755. Tartu: Tartu Ülikooli kirjastus.

Erelt, Mati. 2017c. Sekundaartarindiga laused. Mati Erelt \& Helle Metslang (toim.), Eesti keele süntaks (Eesti keele varamu III), 756-840. Tartu: Tartu Ülikooli kirjastus.

Erelt, Mati. 2019. Lause õigekeelsus: juhatused ja harjutused, 4., täiendatud trükk. Tallinn: Emakeele Selts.

Gijn, Rik van, Jeremy Hammond, Dejan Matić, Saskia van Putten \& Ana Vilacy Galucio (toim.). 2014. Information structure and reference tracking in complex sentences 
(Typological Studies in Language 105). Amsterdam: John Benjamins. https://doi. org/10.1075/tsl.105.

Goldberg, Adele. 1995. Constructions: A construction grammar approach to argument structure. Chicago: University of Chicago Press.

Gundel, Jeanette \& Thorstein Fretheim. 2004. Topic and focus. Larry Horn \& Gregory Ward (toim.), The handbook of pragmatics, 175-196. Malden, MA: Blackwell Publishers. https://doi.org/10.1002/9780470756959.ch8.

Haiman, John. 1978. Conditionals are topics. Language 54(3). 565-589. https://doi. org $/ 10.2307 / 412787$.

Halliday, Michael A. K. 1967. Notes on transitivity and theme in English: part 2. Journal of Linguistics 3(2). 199-244. https://doi.org/10.1017/S0022226700016613.

Halliday, Michael A. K. 1985. An introduction to functional grammar. London: Arnold.

Haspelmath, Martin 1995. The converb as a cross-linguistically valid category. Martin Haspelmath \& Ekkehard König (toim.), Converbs in cross-linguistic perspective, 1-55. Berlin: Mouton de Gruyter. https://doi.org/10.1515/9783110884463.

Ibarluzea, Patxi Laskurain. 2014. Mood selection in the complement of negation matrices in Spanish. Rik van Gijn, Jeremy Hammond, Dejan Matić, Saskia van Putten \& Ana Vilacy Galucio (toim.), Information structure and reference tracking in complex sentences (Typological Studies in Language 105), 193-228. Amsterdam: John Benjamins. https://doi.org/10.1075/tsl.105.01mat.

Jacobs, Joachim. 2001. The dimensions of topic-comment. Linguistics 39(4). 641-681. https://doi.org/10.1515/ling.2001.027.

Khalilova, Zaira. 2009. A Grammar of Khwarshi (Landelijke Onderzoekschool Taalwetenschap 234). Utrecht: LOT.

Killie, Kristin \& Toril Swan. 2009. The grammaticalization and subjectification of adverbial -ing clauses (converb clauses) in English. English Language and Linguistics 13(3). 337-363. https://doi.org/10.1017/S1360674309990141.

Kinberg, Naphtali. 2001. Adverbial clauses as topics in Arabic: adverbial clauses in frontal position separated from their main clause. Naphtali Kinberg \& Kees Versteegh (toim.), Studies in the linguistic structure of classical Arabic, 43-102. Leiden: Brill.

Komen, Erwin R. 2014. Chechen extraposition as an information ordering strategy. Rik van Gijn, Jeremy Hammond, Dejan Matić, Saskia van Putten \& Ana Vilacy Galucio (toim.), Information structure and reference tracking in complex sentences, 99-126. Amsterdam: John Benjamins. https://doi.org/10.1075/tsl.105.01mat.

Koptjevskaja-Tamm, Maria. 1993. Nominalizations. London: Routledge.

Kortmann, Bernd. 1991. Free adjuncts and absolutes in English: problems of control and interpretation. London / New York: Routledge.

Krifka, Manfred. 2007. Basic notions of information structure. Catherine Féry, Gisbert Fanselow \& Manfred Krifka (toim.), The notions of information structure (Interdisciplinary Studies on Information Structure 6(2007)), 13-55. Potsdam: Universitätsverlag Potsdam.

Krifka, Manfred \& Catherine Féry. 2008. Information structure. Notional distinctions, ways of expression. Piet van Sterkenburg (toim.), Unity and diveristy of languages, 123-136. Amsterdam: John Benjamins. 
König, Ekkehard. 1995. The meaning of converb constructions. Martin Haspelmath \& Ekkehard König (toim.), Converbs in cross-linguistic perspective (Empirical Approaches to Language Typology 13), 57-96. Berlin: Mouton de Gruyter. https:// doi.org/10.1515/9783110884463-004.

Lambrecht, Knud. 1994. Information structure and sentence form. Cambridge: Cambridge University Press.

Lambrecht, Knud. 2000. When subjects behave like objects: An analysis of the merging of $\mathrm{S}$ and $\mathrm{O}$ in sentence-focus constructions across languages. Studies in Language 24(3). 611-682. https://doi.org/10.1075/s1.24.3.06lam.

Lindström, Liina. 2005. Finiitverbi asend lauses. Sõnajärg ja seda mõjutavad tegurid suulises eesti keeles (Dissertationes philologiae estonicae Universitatis Tartuensis 16). Tartu: Tartu Ülikooli kirjastus.

Lindström, Liina. 2006. Infostruktuuri osast eesti keele sõnajärje muutumisel. Keel ja Kirjandus 49(11). 875-888.

Lindström, Liina. 2017. Lause infostruktuur ja sõnajärg. Mati Erelt \& Helle Metslang (toim.), Eesti keele süntaks (Eesti keele varamu III), 537-565. Tartu: Tartu Ülikooli kirjastus.

Martõkainen, Liina. 2015. des-konstruktsiooni sõnajärg. Tartu: Tartu Ülikooli eesti keele osakond. Bakalaureusetöö.

Matić, Dejan. 2009. On the variability of focus meanings. Proceedings of the 18th International Congress of Linguistics, Seoul 2008. Seoul: Linguistic Society of Korea.

Matić, Dejan \& Daniel Wedgwood. 2013. The meanings of focus: The significance of an interpretation-based category in cross-linguistic analysis. Journal of Linguistics 49(1). 127-163. https://doi.org/10.1017/S0022226712000345.

Matić, Dejan, Rika van Gijn \& Robert D. van Valin, Jr. 2014. Rik van Gijn, Jeremy Hammond, Dejan Matić, Saskia van Putten \& Ana Vilacy Galucio (toim.), Information structure and reference tracking in complex sentences (Typological Studies in Language 105), 1-41. Amsterdam: John Benjamins. https://doi.org/10.1075/ tsl.105.01mat.

Matić, Dejan \& Irina Nikolajeva. 2018. From polarity focus to salient polarity: From things to processes. Christine Dimroth \& Stefan Sudhoff (toim.), The grammatical realization of polarity contrast: Theoretical, empirical, and typological approaches (Linguistik Aktuel1/Linguistics Today 249), 9-54. Amsterdam: John Benjamins. https://doi.org/10.1075/la.249.01mat.

Mihkla, Meelis \& Heete Sahkai. 2017. Lauserõhu akustilised korrelaadid eesti keeles. Mäetagused 68. 161-176. https://doi.org/10.7592/MT2017.68.mihkla_sahkai.

Moore, Nick. 2016. What's the point? The role of punctuation in realising infomation structure in written English. Functional Linguistics 3(6). 1-23. http://dx.doi. org/10.1186/s40554-016-0029-x.

Nedjalkov, Igor. 1998. Converbs in the languages of Eastern Siberia. Language Sciences 20(3). 339-351.

Neeleman, Ad, Elena Titov, Hans van de Koot \& Reiko Vermeulen. 2009. A syntactic typology of topic, focus and contrast. Jeroen van Craenenbroeck (toim.), Alternatives to cartography (Studies in Generative Grammar 100), 15-51. Berlin: Mouton de Gruyter. http://dx.doi.org/10.1515/9783110217124.15. 
Nikolajeva, Irina. 2001. Secondary topic as a relation in information structure. Linguistics 39(1). 1-49. https://doi.org/10.1515/ling.2001.006.

Plado, Helen. 2015a. des- ja mata-konverbi kasutusest eesti murretes. Emakeele Seltsi aastaraamat 60(2014). 195-218. https://doi.org/10.3176/esa60.10.

Plado, Helen. 2015b. The subject of the Estonian des-converb. SKY Journal of Linguistics 28. 313-348.

Putten, Saskia van. 2014. Left dislocation and subordination in Avatime (Kwa). Rik van Gijn, Jeremy Hammond, Dejan Matić, Saskia van Putten \& Ana Vilacy Galucio (toim.), Information structure and reference tracking in complex sentences (Typological Studies in Language 105), 71-98. Amsterdam: John Benjamins.

Reesink, Ger P. 2014. Topic management and clause combination in the Papuan language Usan. Rik van Gijn, Jeremy Hammond, Dejan Matić, Saskia van Putten \& Ana Vilacy Galucio (toim.), Information structure and reference tracking in complex sentences (Typological Studies in Language 105), 231-262. Amsterdam: John Benjamins. https://doi.org/10.1075/tsl.105.08ree.

Reinhart, Tanya. 1981. Pragmatics and linguistics: An analysis of sentence topics in pragmatics and philosophy I. Philosophica anc Studia Philosophica Gadensia Gent 27(1). 53-94.

Remmel, Nikolai. 1963. Sõnajärjestus eesti lauses. Eesti keele süntaksi küsimusi (Keele ja Kirjanduse Instituudi uurimused VIII), 216-389. Tallinn: Eesti Riiklik Kirjastus.

Sahkai, Heete. 1999. Eesti verbifraasi sõnajärg. Keel ja Kirjandus 42(1). 24-32.

Sahkai, Heete. 2011. Eesti keele genitiivse agendifraasi süntaks. Keel ja Kirjandus 54(10). 790-807.

Sahkai, Heete, Meelis Mihkla \& Mari-Liis Kalvik. 2015. Emfaas ja fookus eesti keeles. Eesti ja soome-ugri keeleteaduse ajakiri. Journal of Estonian and Finno-Ugric Linguistics 6(3). 97-122. https://doi.org/10.12697/jeful.2015.6.3.04.

Simmul, Carl Eric. 2017. des- ja mata-konverbitarindi funktsioonid. Tartu: Tartu Ülikooli eesti keele osakond. Magistritöö.

Simmul, Carl Eric. 2018. des- ja mata-konverbitarindi funktsioonid. Keel ja Kirjandus 59(11). 847-867.

Simmul, Carl Eric. 2020. Süüvides jonni jätmata avamaks sõnajärjemustreid. des-, mata- ja maks-konverbitarindi sõnajärg. Keel ja Kirjandus 61(3). 221-242.

Storto, Luciana. 2014. Constituent order and information structure in Karitiana. Rik van Gijn, Jeremy Hammond, Dejan Matić, Saskia van Putten \& Ana Vilacy Galucio (toim.), Information structure and reference tracking in complex sentences (Typological Studies in Language 105), 163-192. Amsterdam: John Benjamins. https:// doi.org/10.1075/tsl.105.06sto.

Zimmermann, Malte \& Caroline Féry. 2010. Introduction - information structure. Malte Zimmermann \& Caroline Féry (toim.), Information structure: Theoretical, typological, and experimental perspectives, 1-11. Oxford: Oxford University Press.

Tael, Kaja. 1988. Sõnajärjemallid eesti keeles (võrrelduna soome keelega) (Preprint KKI-56). Tallinn: ENSV TA Keele- ja Kirjanduse Instituut.

Thompson, Sandra A \& Li, Charles N. 1976. Subject and topic: A new typology of language. Charles N. Li (toim.), Subject and topic, 457-489. New York: Academic Press. 
Thompson, Sandra A., Robert E. Longacre \& Shin Ja J. Hwang. 2007. Adverbial clauses. Timothy, Shopen (toim.), Language typology and syntactic description, 2nd edn., 171-234. Cambridge: Cambridge University Press. https://doi.org/10.1017/ CBO9780511619434.005.

Tikkanen, Bertil. 2001. Converbs. Martin Haspelmath, Ekkehard König, Wulf Oesterreicher \& Wolfgang Raible (toim.), Language typology and language universals / Sprachtypologie und sprachliche Universalien / La typologie des languages et les universaux linguistiques. An international handbook / Ein internationales Handbuch / Manuel international (Handbücher zur Sprach- und Kommunikationswissenschaft / Handbooks of Linguistics and Communication Science 20(2)), 1112-1123. Berlin/New York: Mouton de Gruyter.

Uuspõld, Ellen. 1966. Määrusliku des-, mata-, nud-( nuna-) ja tud- ( tuna-) konstruktsiooni struktuur ja tähendus. Keele modelleerimise probleeme I (Tartu Riikliku Ülikooli toimetised 188), 1-196. Tartu: Tartu Riiklik Ülikool.

Uuspõld, Ellen. 1972. Agendi väljendamisest des-konstruktsiooniga lausetes. Keel ja struktuur 7, 108-118. Tartu: Tartu Riiklik Ülikool.

Valijärvi, Riitta-Liisa. 2003. Estonian converbs - with special emphasis on early 18thcentury literary languages. Ural-Altaische Jahrbucher 18. 24-67.

Wal, Jenneke van der. 2014. Subordinate clauses and exclusive focus in Makhuwa. Rik van Gijn, Jeremy Hammond, Dejan Matić, Saskia van Putten \& Ana Vilacy Galucio (toim.), Information structure and reference tracking in complex sentences (Typological Studies in Language 105), 45-70. Amsterdam: John Benjamins. https://doi. org/10.1075/tsl.105.02van.

Ylikoski, Jussi. 2003. Defining non-finites: action nominals, converbs and infinitives. SKY Journal of Linguistics 16. 185-237.

Abstract. Carl Eric Simmul: The informational role of Estonian
-des, -mata and -maks converb constructions. This article discusses the complex clauses that entail an Estonian -des, -mata or -maks converb construction, i.e., an infinite construction functioning as a free modifier. The article is based on a study of 1803 sentences entailing a converb construction, and gives an overview of the informational roles of the converb construction as well as the main factors of its variation. The study revealed that the Estonian converb construction has four main informational roles: 1) frame-setting topic, 2) background of the comment, 3) focused part of the comment and 4) distinct information unit. The informational role of a converb construction mainly depends on the word order. A construction starting with a converb normally functions as a distinct information unit. A construction ending with a converb or consisting only of a converb normally forms an unitary information 
unit together with the main clause. The specific informational role of the construction ending with a converb or consisting only of a converb is dependent on the position of the construction: constructions located before the main clause function as topics, constructions located inside the main clause function as the background part of the comment, constructions located after the main clause function as foci. Other important factors related to the informational role are, for example, the interpunction, the communicative type of the main clause, focusing adverbs, the semantic function of the converb construction, the length and structure of the arguments of the converb construction.

Keywords: converb, word order, information structure, syntax, semantics, Estonian 